\title{
TBX1 wt Allele
}

National Cancer Institute

\section{Source}

National Cancer Institute. TBX1 wt Allele. NCI Thesaurus. Code C75412.

Human TBX1 wild-type allele is located in the vicinity of $22 \mathrm{q} 11.21$ and is approximately 27 $\mathrm{kb}$ in leng th. This allele, which encodes T-box transcription factor TBX1, plays roles in regulation of transcription, proliferation of the thymus and auditory epithelium, and function of the parathyroid and heart. Mutations in this wt allele are associated with many features of 22q11.2 deletion syndrome. 